\title{
TELAAH KEJAHATAN KEMANUSIAAN TERHADAP ETNIS ROHINGYA BERDASARKAN HUKUM INTERNASIONAL
}

\author{
Inggrit Fernandes \\ Dosen Hukum Internasional Fakultas Hukum Universitas Islam Indragiri \\ Email: inggritff@yhaoo.com
}

\begin{abstract}
International law is a law whose enforcement depends on the good faith of the countries that are members of the world community. It can only be imposed if the state does not have the power of lobbying in international relations. The proof of many countries that violate the law of intrenasional but has a strong ally then he is detached from the bondage of international law itself. International humanitarian law has been in existence since the formation of the United Nations but its implementation has been dulled by the high-level lobby of the UN Security Council. Crimes against ethnic Rohingya should be prosecuted in the International Criminal Court (ICC) because there are already elements of violations in the Rome Statute 1998.
\end{abstract}

Keywords: Crime, Humanity, Rohingya.

\begin{abstract}
Abstrak
Hukum internasional aalah kaedah hukum yang penegakannya bergantung kepada itikad baik negara-negara yang tergabung dalam masyarakat dunia. Ia hanya dapat dipaksakan jika negara tidak memiliki keuatan lobi dalam pergaulan internasional. Buktinya banyak negara yang melanggar hukum intrenasional namun memiliki sekutu yang kuat maka ia terlepas dari jeratan hukum internasional itu sendiri. Hukum internasional tentang kemanusiaan sudah ada sejak terbentuknya organisasi Perserikatan Bangsa-Bangsa (United Nations) namun pelaksanaannya terasa tumpul karena lobi tingkat tinggi di Dewan Keamanan PBB. Kejahatan terhadap etnis Rohingya seharusnya sudah dapat di adili di International Criminal Court (ICC) karena sudah terpenuhinya unsur-unsur yang terdapat dalam Statuta Roma 1998.
\end{abstract}

Kata Kunci: Kejahatan, Kemanusiaan, Rohingya.

\section{Pendahuluan}

Rohingya adalah sebuah kelompok etnis Indo-Arya dari Rakhine (juga dikenal sebagai Arakan, atau Rohang dalam bahasa Rohingya) di Myanmar. Rohingya adalah etno- 
linguistik yang berhubungan dengan bahasa bangsa Indo-Arya di India dan Bangladesh (yang berlawanan dengan mayoritas rakyat Myanmar yang Sino-Tibet). ${ }^{1}$ Menurut penuturan warga Rohingya dan beberapa ulama, mereka berasal dari negara bagian Rakhine. Sedangkan sejarawan lain mengklaim bahwa mereka bermigrasi ke Myanmar dari Bengal terutama perpindahan yang berlangsung selama masa pemerintahan Inggris di Burma. ${ }^{2}$

Permukiman Muslim di Arakan telah ada sejak abad ke-7 Masehi. Sumber lain menyebutkan bahwa Arakan atau Rohang, kemudian menjadi Kesulatanan Islam yang didirikan oleh Sultan Sulaiman Syah dengan bantuan masyarakat muslim di Bengal (Bangladesh). Kerajaan / Kesultanan Arakan berdiri pada tahun 1430 hingga 1784, berarti Kaum Muslimin memerintah wilayah Arakan lebih dari 3,5 abad. Arakan kian ramai oleh pendatang dari berbagai macam suku bangsa, pencampuran suku ini akhirnya membentuk suku baru yakni Rohingya, oleh karenanya Muslim Rohingya sudah ada di Arakan sejak abad ke 7.

Rohingya sudah ada di Rakhine atau Bruma sejak generasi terdahulu. Namun, klaim tersebut tidak berhasil. Mereka tidak mendapatkan pengakuan dari Myanmar dan keberadaannya diperdebatkan oleh kaum Buddha yang merupakan mayoritas di negara tersebut. Begitulah penjelasan singkat soal Rohingya menurut Jacques $\mathrm{P}$ Leider dalam tulisannya bertajuk Rohingnya: The Name, The Movement, and The Quest for Identity. ${ }^{3}$

Rohingya tidak dianggap ke dalam 135 etnis resmi negara Myanmar. Mereka juga telah ditolak kewarganegaraannya di Myanmar sejak 1982, yang secara efektif membuat mereka tanpa kewarganegaraan di tempat tinggalnya. Sejak tahun 1948 Myanmar ketika Myanmar merayakan kemerdekaannya, sudah ada sekitar 1,5 juta orang Rohingnya yang meninggalkan tempat tinggalnya. Para pengungsi Rohingya kebanyakan ditemukan di Bangladesh, Pakistan, Arab Saudi, Thailand, dan Malaysia. ${ }^{4}$ Dari tahun ke tahun kondisi etnis minoritas Muslim Rohingya tidak membaik di negara Myanmar. Puluhan ribu etnis Rohingya banyak karena desa-desa mereka dibakari tentara Myanmar dan bahkan mereka mengalami perlakuan yang tidak manusiawi.

Media internasional dan organisasi hak asasi manusia menggambarkan Rohingya sebagai salah satu etnis minoritas yang paling teraniaya di dunia. ${ }^{5}$ Menghindari kekerasan di daerahnya banyak di antara orang-orang Rohingya yang melarikan diri ke pemukiman-pemukiman kumuh dan kamp-kamp pengungsi di negara tetangga Bangladesh. ${ }^{6}$ lebih dari 100.000 Rohingya di Myanmar dan hidup sebagiannya lagi hidup sebagai pengungsi. Perlakuan terhadap etnis Rohingya telah menuai perhatian internasional setelah terjadi kerusuhan di negara bagian Rakhine pada tahun 2012. Lalu pada tahun 2015 ketika berlangsungnya perhatian internasional atas krisis Pengungsi Rohingya dimana orang-orang Rohingya menempuh perjalanan laut yang berbahaya dalam upaya melarikan diri ke beberapa negara Asia Tenggara, sebagian ada yang terdampar di Indonesia.

Melihat dari apa yang terjadi pada etnis Rohingya sudah mengarah kepada tindakan kejahatan terhadap etnis tetentu yang dalam hukum intrenasional dikenal dengan istilah

\footnotetext{
${ }^{1}$ https://id.wikipedia.org/wiki/rohingya, diakses 30 November 2017. Pukul 10.52 WIB

${ }^{2}$ Selth, Andrew ,Burma's Muslims: Terrorists or Terrorised?. Australia: Strategic and Defence Studies Centre, 2003, Australian National University. p. 7. ISBN 073155437X.

${ }^{3}$ http://internasional.republika.co.id/berita/internasional/global/17/09/03/ovp7fi-sejarah-singkat-rohingyadi-myanmar, diakses 30 November 2017. Pukul 10.57 WIB

${ }^{4}$ Ibid

${ }^{5}$ https://id.wikipedia.org/wiki/Rohingya\#CITEREFCrisis_Group2014

${ }^{6}$ Ridwanul Hoque (16 March 2016). "Asian cHlmlenge". D+C, development and cooperation
} 
Genosida. Kata genosida pertama kali diperkenalkan oleh seorang akademisi berdarah PolandiaYahudi bernama Raphael Lemkin. Dalam tulisannya, Lemkin mengatakan bahwa:

"The crime of genocide involves a wide range of actions, including not only deprivation of life but also the prevention of life (abortions, sterilizations) and also devices considerably endangering life and health (deliberate separation of families for depopulation purposes and so forth) ..... The acts are directed against groups, as such, and individuals are selected for destruction only because they belong to these groups."

Sebagaimana diterjemahkan sebagai berikut:

"Kejahatan genosida mencakup tindakan yang luas, tidak hanya pembunuhan tapi juga mencegah adanya keturunan (aborsi, sterilisasi) dan juga sarana yang dianggap membahayakan nyawa dan kesehatan (pemisahan keluarga secara paksa dengan tujuan untuk mengurangi populasi, dan sebagainya. Tindakan-tindakan tersebut ditujukan terhadap suatu kelompok dan beberapa individu yang menjadi anggota dari kelompok terebut."

Deklarasi yang dibuat oleh Majelis Umum Perserikatan Bangsa-Bangsa dalam Resolusi 96 (I) tanggal 11 Desember 1946 menyatakan bahwa Genosida adalah merupakan kejahatan menurut hukum internasional, bertentangan dengan jiwa dan tujuan-tujuan Perserikatan BangsaBangsa, dan dikutuk oleh dunia yang beradab.

Dalam Mukadimah Deklarasi Sedunia tentang Hak-hak Asasi Manusia, menyatakan bahwa bangsa-bangsa yang tergabung dalam Perserikatan Bangsa-bangsa sepakat menjunjung tinggi hak-hak dasar manusia, martabat dan penghargaan seseorang manusia dan hak-hak yang sama dari laki-laki maupun perempuan dan telah memutuskan akan memajukan kemajuan sosial dan tingkat penghidupan yang lebih baik dalam kemerdekaan yang lebih luas. ${ }^{7}$ Pasal 1 Deklarasi sedunia tentang Hak-hak asasi Manusia 1948 menyatakan bahwa, semua orang dilahirkan merdeka dan mempunyai martabat dan hak-hak yang sama. Mereka dikaruniai akal dan budi dan hendaknya bergaul satu sama lain dalam pergaulan. ${ }^{8}$

Pasal 3 Piagam menyatakan setiap orang berhak atas penghidupan, kemerdekaan dan keselamatan. Pasal 5 juga menyebutkan bahwa tidak seorang pun boleh dianiaya atau diperlakukan secara kejam, dengan tidak mengingat kemanusiaan ataupun jalan perlakuan atau hukum yang menghinakan sedangkan tentang penahanan terhadap seseorang dinyatakan dalam Pasal 9 Piagam bahwa, tidak seorang pun boleh ditahan atau dibuang secara sewenang-wenang. Sementara itu dalam Pasal 13 piagam menyebutkan bahwa setiap orang berhak atas kebebasan bergerak dan berdiam di dalam lingkungan batas-batas tiap negara.

Dalam Konvensi Tentang Pencegahan Dan Hukuman Terhadap Kejahatan Pemusnahan Suatu Bangsa Dengan Sengaja Tahun 1948 menyatakan peserta konvensi menegaskan bahwa pemusnahan suatu bangsa dengan sengaja, baik yang dilakukan pada waktu damai maupun perang, merupakan kejahatan menurut hukum internasional yang melakukan pencegahan dan penghukuman. Sementara Pasal 4 nya menyatakan orang-orang yang melakukan pemusnahan

\footnotetext{
${ }^{7}$ Deklarasi Sedunia Tentang Hak Asasi Manusia Tahun 1948

${ }^{8}$ Ibid
} 
suatu bangsa dengan sengaja atau sesuatu perbuatan lain harus dihukum apakah mereka penguasa yangbertanggung jawab secara konstitusional, pejabat, maupun perorangan. ${ }^{9}$

Menurut J.G. Starke hukum internasional adalah sekumpulan hukum yang untuk sebagian besar terdiri dari azas-azas dan peraturan-peraturan tingkah laku di mana negara-negara itu sendiri merasa terikat dan menghormatinya, dan dengan demikian negara-negara itu juga harus menghormati atau mematuhinya dalam hubungannya satu sama lain, dan yang juga mencakup :

a. peraturan-peraturan hukum yang berkenaan dengan berfungsinya lembagalembaga atau organisasi-organisasi internasional, hubungan antara organisasi internasional dengan organisasi internasional lainnya, hubungan antara organisasi internasional dengan negara serta hubungan antara organisasi internasional dengan individu,

b. peraturan-peraturan hukum tertentu yang berkenaan dengan individu-individu dan subyek-subyek hukum bukan negara (non state entities) sejauh hak-hak dan kewajiban individu dan subyek hukum bukan negara itu bersangkut paut dengan persoalam masyarakat internasional.

Melihat kondisi penindasan, penyiksaan dan penggusiran etnis Rohingya yang ada di Myanmar seolah-olah Myanmar tidak mengindahkan bergbagai konvensi Intrnasional tentang kejahatan kemanusiaan. Ketidakpatuhan Myanmar terhadap kaidah hukum internasional ini harusnya mendapatkan penindakan yang tegas dari masyarakat internasional.

Dalam Pasal I Ayat 2 Deklarasi Tentang Perlindungan Dari penyiksaan, 1975. menyatakan bahwa penyiksaan merupakan suatu bentuk perlakuan yang kejam, tidak manusiawi atau penghinaan atau penghukuman yang menyakitkan hati dengan sengaja. Pasal 2 nya menyebutkan suatu tindakan penyiksaan atau perlakuan yang kejam tidak manusiawi atau penghukuman adalah pelanggaran terhadap martabat manusia dan harus dikutuk ksebagai pengHlmang piagam Perserikatan Bangsa-bangsa dan pelanggaran Hak-hak asasi manusia dan kebebasan hakiki sperti yang dinyatakan dalam Deklarasi Sedunia mengenai Hak-hak Asasi Manusia.

\section{Metode Penelitian}

\section{Pendekatan Penelitian}

Pendekatan masalah yang digunakan dalam penelitian ini adalah penelitian hukum Normatif. Penelitian hukum normatif adalah penelitian hukum yang dilakukan dengan cara meneliti bahan pustaka dan data sekunder. ${ }^{10}$

\section{Jenis dan Data}

Pada penelitian hukum Normatif, bahan pustaka merupakan data dasar yang dalam (ilmu) penelitian digolongkan sebagai data sekunder. Apabila dilihat dari sudut sifat informasi yang diberikannya, maka bahan pustaka dapat dibagi dalam tiga kelompok sebagai berikut:

1. Bahan hukum primer, yakni bahan pustaka yang berisikan pengetahuan ilmiah yang baru atau mutakhir, ataupun pengertian baru tentang fakta yang diketahui maupun mengenai suatu gagasan (ide). Bahan / sumber primer ini mencakup:

\footnotetext{
${ }^{9}$ Brownlie(Penerjemah:Beriansyah), 1999, Kompilasi Konvensi Tentang Pencegahan Dan Hukuman Terhadap Kejahatan Pemusnahan Suatu Bangsa Dengan Sengaja Tahun 1948, UI Press, Jakarta, hlm. 40

${ }^{10}$ Sorjono soekanto, 2006, Penelitian hukum Normatif, PT Raja Grafindo Persada, Jakarta, hlm. 14
} 
a) konvensi Internasional

b) Resolusi PBB

c) Buku

d) Laporan Penelitian

e) Jurnal Ilmiah

2. Bahan hukum sekunder, yaitu bahan pustaka yang berisikan informasi tentang bahan primer. ${ }^{11}$

3. Bahan hukum tertier, yakni bahan-bahan yang memberi petunjuk maupun penjelasan terhadap bahan hukum primer dan sekunder, misalnya kamus-kamus, ensiklopedia, dan sebagainya. Agar diperoleh informasi yang terbaru dan berkaitan erat dengan permasalahannya, maka kepustakaan yang dicari dan dipilih revelen dan mutakhir. ${ }^{12}$

\section{Analisis data}

Setelah data-data terkumpul maka peneliti melakukan analisa dengan cara deskriptif yakni dengan menggambarkan hasil penelitian yang telah diteliti kemudian dengan penarikan kesimpulan secara deduktif.

\section{Pembahasan}

\section{Telaah Kejahatan Genosida Terhadap Etnis Rohingya Berdasarkan Hukum Internasional}

Perbuatan yang dinyatakan sebagai kejahatan terhadap kemanusiaan adalah pembunuhan, pemusnahan dan perbudakan. ${ }^{13}$ Tindakan pengusiran, penyiksaan, pemusnahan dan tindakan tidak manusiawi lainnya yang dilakukan terhadap etnis Rohingya atau pembatasan berdasarkan agama, ras, politik, yang dilakukan berkaitan dengan pelaksanaan atau yang berhubungan dengan kejahatan terhadap perdamaian atau kejahatan perang. ${ }^{14}$ Dalam konteks hukum internasional terdapat beberapa konvensi, deklarasi dan perjanjian Internasional yang mengaturnya.

\section{a. Konvensi Internasional Tentang Hak Sipil Dan Politik Tahun 1966}

Pasal 6 Ayat 1 Konvensi Internasional tentang Hak Sipil Dan Politik tahun 1966 menyatakan bahwa, setiap manusia melekat hak untuk hidup, hak ini harus dilindungi oleh hukum. Tidak seorang pun boleh dirampas kehidupannya secara sewenang-wenang. ${ }^{15}$ Myanmar melakukan praktik-praktik yang melanggar Konvensi diatas yaitu pembunuhan yang dilakukan terhadap etnis Rohingya yang dilindungi.

\footnotetext{
${ }^{11}$ Op. Cit hlm 29

12 Op. Cit, hlm 117

${ }^{13}$ M.Cherif Bassiouni, 1986, International criminal law, dikutip dari Shinta Agustina, 2006, Hukum Pidana Internasional Dalam Teori dan Praktek, 2006, Andalas University Press, Padang, hlm. 64

14 Ibid

${ }^{15}$ Op. Cit. Ian Brownlie, hlm 172
} 


\section{b. Konvensi Tentang Pencegahan Dan Hukuman Terhadap Kejahatan Pemusnahan Suatu Bangsa Dengan Sengaja Tahun 1948}

Pemusnahan suatu bangsa merupakan suatu kejahatan menurut hukum internasional. Pasal 1 Konvensi menyebutkan bahwa negara-negara peserta Konvensi menegaskan bahwa pemusnahan suatu bangsa dengan sengaja, baik yang dilakukan diwaktu damai maupun pada waktu perang merupakankejahatan menurut hukum internasional yang melakukan pencegahan dan penghukuman.

Pada Oktober 2012, Presiden Burma, Thein Sein mengakui bahwa komunitas Rohingya telah menjadi korban kekerasan etnis di negara itu. Ada 2.800 rumah telah dibakar pada kerusuhan saat itu. Sebuah gambar satelit yang dikeluarkan lembaga internasional memperlihatkan terjadinya kerusakan dalam skala besar di kota Kyaukpyu, pada bagian distrik yang sebelumnya didiami oleh komunitas Rohingya. Areal yang hancur mencapai 14,5 hektar dan sekitar 811 bangunan dan rumah-rumah perahu di wilayah itu telah musnah. ${ }^{16}$ Pembunuhan terhadap etnis Rohingya ini masih berlangsung hingga saat ini.

Pasal 2 Konvensi ini mengidentifikasi suatu perbuatan yang dilakukan dengan sungguhsungguh untuk menghancurkan seluruh atau sebagian suatu bangsa, suku bangsa, ras atau jenis kelompok keagamaan, diantara perbuatan itu adalah:

1. Membunuh anggota-anggota kelompok

2. Merusak jasmani atau mental anggota-anggota kelompok

3. Dengan sengaja mengakibatkan penderitaan pada kondisi kehidupan suatu kelompok yang diperkirakan menimbulkan kerusakan jasmani selurunya atau sebagian

4. Melaksanakan tindakan yang ditujukan untuk mencegah kelahiran dalam suatu kelompok

5. Memindahkan anak-anak dari suatu kelompok ke kelompok lain secara paksa. Pasal 3 menyatakan bahwa, perbuatan berikut dibawah ini dapat dihukum yaitu:

a) Pemusnahan suatu bangsa dengan sengaja.

b) Komplotan rahasia yang melakukan pemusnahan suatu bangsa dengan sengaja.

c) Hasutan langsung dan terbuka untuk melakukan pemusnahan suatu bangsa dengan sengaja.

d) Usaha melakukan pemusnahan suatu bangsa dengan sengaja.

e) Ketertiban dalam pemusnahan suatu bangsa dengan sengaja.

Pembunuhan, pengusiran, dan pemusnahan Rohingya merupakan salah satu tragedi kemanusiaan yang sangat dahsyat selama abad ke-20 dan ke-21 ini. Pemusnahan (genosida) Rohingya secara sistemetis ini jelas-jelas merupakan kejahatan dan tragedi kemanusiaan yang sangat memprihatinkan di dunia yang beradab. Sudah sepatutnya, dunia internasional bersuara atas kejadian ini. Lembaga HAM Human Right Watch dalam laporannya soal tragedi tahun 2012 yang membuat 125 ribu Rohingya terusir ke Bangladesh belum kembali hingga sekarang menyebut kekerasan terhadap etnis minoritas Muslim itu adalah "pembersihan etnis" atau genosida. $^{17}$

\footnotetext{
${ }^{16}$ https:// www.petisionline.net./hentikan\%20pembantaian\%20dan\%20pemusnahan\%20rohingya\%20\%20petisionline.net.html, diakses pada 5 Desember 2017,Pukul 10.53 Wib.

${ }^{17}$ https://www.hrw.org/report/2013/04/22/all-you-can-do-pray/crimes-against-humanity-and-ethniccleansing-rohingya-muslims, diakses 27 November 2017, Pukul 11.24. Wib
} 
Tanda-tanda genosida jelas terlihat, walau pemerintah Myanmar membantahnya. Menurut situs berita PBB, UN Dispatch, Myanmar telah memenuhi delapan tahapan genosida yang ditetapkan oleh organisasi pencegah genosida, Genocide Watch. ${ }^{18}$

Di antara delapan langkah genosida tersebut adalah: Klasifikasi, simbolisasi, dehumanisasi, terorganisir, polarisasi, persiapan, dan penyangkalan

\section{c. Deklarasi Tentang Perlindungan Dari Penyiksaan tahun $1975^{19}$}

Menurut Pasal 1 Ayat 1 Deklarasi Tentang Perlindungan Dari Penyiksaan Tahun 1975 penyiksaan berarti setiap tindakan yang mengakibatkan rasa sakit sekali atau penderitaan, baik pada jasmani maupun rohani, yang dilakukan dengan maksud tertentu atas anjuran pejabat pemerintah terhadap seseorang dengan maksud memperoleh darinya atau orang ketiga atau pengakuan, menghukumnya karena perbuatan yang telah dilakukan atau dicurigai karena melakukan, atau menakut-nakutinya atas orang lain.tidak termasuk kesakitan atau penderitaan yang timbul hanya dari, yang sudah melekat atau sekali-sekali pada sanksi hukum yang sampai tingkat tertentu konsisten dengan peraturan standar minimum bagi perlakuan terhadap orang hukuman. $^{20}$

Pasal 1 Ayat 2 Deklarasi Tentang Perlindungan Dari Penyiksaan Tahun 1975 menyatakan bahwa penyiksaan merupakan bentuk perlakuan yang kejam, tidak manusiawi atau penghinaan atau penghukuman yang menyakitkan hati dan sengaja. Pasal 2 Deklarasi ini menyatakan bahwa penyiksaan merupakan suatu bentuk perlakuan yang kejam, tidak manusiawi atau penghinaan atau penghukuman adalah pelanggaran terhadap martabat manusia dan harus dikutuk sebagai penghalang tujuan Perserikatan bangsa-bangsa dan pelanggaran terhadap hak-hak asasi manusia dan kebebasan hakiki seperti yang dinyatakan dalam deklarasi sedunia mengenai hak-hak asasi manusia.

Pasal 3 Deklarasi menyatakan, setiap negara janganlah mengizinkan atau membiarkan penyiksaan atau perlakuan kejam, tidak manusiawi atau penghinaan atau penghukuman. Keadaan yang luar biasa seperti keadaan perang atau ancaman perang, kerawanan politik dalam negeri atau suatau keadaan darurat tidak boleh dimintakan sebagai alasan pembenaran terhadap penyiksaan atau perlakuan kejam, tidak manusiawi atau penghinaan, atau penghukuman.

\section{d. Deklarasi Hak Asasi Anak Tahun 1959}

Dalam Mukadimah Deklarasi Hak asasi Anak menyatakan bahwa, PBB dalam deklarasi Hak-hak Asasi Manusia, telah menyatakan setiap orang berhak atas semua hak dan kebebasan yang dinyatakan didalamnya, tanpa perbedaan apapun, seperti ras, warna kulit, jenis kelamin, bangsa, agama, pandangan politik atau pandangan lainnya, kebangsaan, atau asal-usul sosial, kekayaan, kelahiran atau status lainnya. ${ }^{21}$

Jumlah anak-anak Rohingya yang mengalami gizi buruk, baik di Myanmar maupun di Bangladesh, meningkat drastis. Sebuah survei baru-baru ini dari Komite Penyelamatan

\footnotetext{
${ }^{18}$ https:// http://www.genocidewatch.org/aboutgenocide/8stagesofgenocide.html. diakses 27 November 2017, Pukul 11.24. Wib

${ }^{19}$ Loc. Cit Ian Brownlie, hlm. 46

${ }^{20}$ Deklarasi Tentang Perlindungan Dari Penyiksaan tahun 1975

${ }^{21}$ Deklarasi Hak Asasi Anak Tahun 1959
} 
Internasional (IRC) bekerja sama dengan Aksi Melawan Kelaparan (ACF) menyatakan, mereka menghadapi peningkatan angka gizi buruk 10 kali lebih tinggi dibandingkan jumlah tahun lalu. Sementara, menurut hasil survei dari Badan PBB untuk Dana Anak-anak (Unicef), 7,5 persen anak-anak Rohingya yang mengungsi di Cox's Bazar, Bangladesh, menderita gizi buruk akut. ${ }^{22}$ Ayat 4 Deklarasi menyatakan, anak harus menikmati tunjangan jaminan sosial. Anak harus diberi kesempatan tumbuh dan berkembang dalam keadaan sehat, demi tujuan ini, perawatan dan perlindungan khusus harus diberikan kepada anak dan ibunya termasuk sebelum lahir dan sesudah lahir. Anak harus mendapatkan hak makanan yang cukup, perumahan, rekreasi dan kesehatan.

Kondisi tersebut membuat mereka membutuhkan penyelamatan segera. Lebih dari 600 ribu orang Rohingya telah melarikan diri dari kekerasan dan penganiayaan di Myanmar sejak 25 Agustus. IRC memperkirakan akan ada pendatang baru di pengungsian Cox's Bazar, Bangladesh, sebanyak 200 ribu orang dalam beberapa pekan mendatang. Maka, jumlah penduduk di Bangladesh akan mencapai 1 juta orang lebih. Hal itu dapat memperburuk krisis tersebut jika tidak segera ditangani. ${ }^{23}$ Ayat 8 Deklarasi menyatakan bahwa, dalam setiap keadaan anak lah yang terlebih dahulu yang harus mendapat pertolongan. Ayat 9 juga menyebutkan hal yang sama, bahwa anak harus dilindungi terhadap semua bentuk kelalaian, kekejaman dan eksploitasi. Anak tidak boleh menjadi sasaran perdagangan dalam segala bentuknya.

Apa yang terjadi terhadap anak-anak Rohingya sudah melanggar Deklarasi Hak Asasi Anak Tahun 1959. Pada Ayat 2 Deklarasi menyatakan Bahwa anak harus menikmati perlindungan khusus dan harus diberikan kesempatan dan fasilitas oleh hukum atau dengan peraturan lainnya, untuk menjamin tumbuhnya jasmaninya, rohaninya, budinya, kejiwaannya, dan kemasyarakatannya dalam keadaan sehat dan wajar dan dalam kond isi yang bebas dan bermartabat. Dalam penetapan hukum untuk tujuan ini, perhatian yang terbaik pada anak harus menjadi pertimbangan utama. Sekitar 40 ribu anak Rohingya berusia antara enam bulan dan lima tahun membutuhkan bantuan untuk menyelamatkan nyawa mereka. Sedangkan, 10 kali lipat bayi dan balita berusia di bawah enam bulan menghadapi ancaman kematian yang fatal, diukur berdasarkan lingkar lengan mereka. Jika diperkirakan, butuh lebih dari 12 juta dolar AS untuk menangani krisis kemanusiaan tersebut. ${ }^{24}$

Ayat 10 menyebutkan bahwa anak, harus dilindungi dari praktik yang mengarah pada diskriminasi ras, aagama, dan bentuk diskriminasi. Anak harus dibesarkan dalam semangat, pengertian, toleransi, persahabatan, antara manusia, perdamaian dan persaudaraan semesta, dan dalam kesadaran penuh bahwa tenaga dan bakatnya harus dapat dibaktikan untuk melayani sesama manusia.

\section{Proses Dan Sanksi Kejahatan Genosida Pada Peradilan Internasional}

Penegakan hukum pidana internasional pada hakekatnya adalah diskusi tentang hukum pidana internasional dalam pengertian formil. Artinya, yang akan di bahas adalah aspek-aspek internasional dalam hukum pidana. Secara teoritis, penegakan hukum pidana internasional dibagi menjadi direct enforcement system (sistem penegakan langsung) dan indirect enforcement system

${ }^{22}$ https://www.republika.co.id, Anak-Anak Rohingya yang Didera Gizi Buruk, Oleh: Crystal Liestia Purnama, diakses 5 Desember 2017.Pukul 10.53 Wib

${ }^{23}$ Ibid

${ }^{24}$ Ibid 
(sistem penegakan tidak langsung). Akan tetapi dalam perkembangannya terdapat apa yang disebut dengan hybrid model atau model campuran yang mengakomodasi penegakan hukum pidana internasional melalui hukum pidana nasional dan hukum internasional. ${ }^{25}$

Penyelesaian terhadap pelanggaran berat HAM secara hukum pada dasarnya mengacu kepada prinsip exhaustion of local remedies melalui mekanisme forum pengadilan nasional. Mekanisme penyelesaian pelanggaran berat HAM ditingkat nasional biasanya dibentuk oleh suatu negara dengan cara mendirikan suatu pengadilan khusus HAM. Pengadilan tersebut ada yang bersifat permanen maupun $A d$ hoc berdasarkan peraturan perundang-undangan nasional negara yang bersangkutan. Pembentukan pengadilan ada yang dilakukan secara mandiri oleh negara yang bersangkutan maupun bekerjasama dengan lembaga Internasional seperti PBB. ${ }^{26}$

Mekanisme penyelesaian pelanggaran berat HAM ditingkat internasional terdiri dari Mahkamah HAM yang bersifat Ad hoc dan Permanen. Mahkamah HAM internasional Ad hoc dibentuk berdasarkan suatu resolusi DK PBB atas dasar ancaman atas keamanan dan perdamaian dunia. ketidakmauan (unwillingness) dan ketidakmampuan (inability) dari negara yang diduga melakukan pelanggaran berat HAM untuk menyelesaikan masalah pelanggaran tersebut di tingkat nasional dapat mendasari dibentuknya Mahkamah Internasional Ad hoc dan diambil alihnya Mahkamah Pidana Internasional (ICC). ${ }^{27}$

Praktek system penegakan hukum langsung telah dilaksanakan oleh beberapa Mahkamah Internasional ad hoc, seperti Nuremberg Trial, Tokyo Trial, hingga ICTY dan ICTR. Sementara penegakan hukum tidak langsung, dilakukan oleh pengadilan nasional tempat tindak pidana terjadi atau pengadilan lain yang mempunyai yurisdiksi atas tindak pidana yang terjadi. ${ }^{28}$

Tanggal 17 Juli 1998 Statuta Roma melahirkan Mahkamah Pidana Internasional. Mahkamah Pidana Internasional berada di bawah PBB dengan tempat kedudukan Den Haag, Belanda. Adapun bahasa resmi yang digunakan oleh Mahkamah Pidana Internasional sama dengan bahasa resmi PBB, yaitu bahasa Arab, bahasa Cina, bahasa Inggris, bahasa Perancis, bahasa Rusia, dan bahasa Spanyol. Badan-badan Mahkamah Pidana Internasional meliputi kepresidenan, devisi banding, devisi pengadilan, devisi prapengadilan, kantor jaksa penuntut umum, dan kepaniteraan. $^{29}$

Pasal 5 ayat (1) Statuta Roma yang berisi ketentuan bahwa, yurisdiksi mahkamah terbatas pada kejahatan paling serius yang menyangkut masyarakat internasional secara keseluruhan. Mahkamah mempunyai yurisdiksi sesuai dengan Statuta berkenan dengan kejahatan-kejahatan berikut: ${ }^{30}$

a) Kejahatan genosida;

b) Kejahatan terhadap kemanusiaan;

c) Kejahatan perang;

d) Kejahatan agresi.

${ }^{25}$ Eddy O.S Hiariej, 2009, Pengantar Hukum Pidana Internasional, Erlangga, Jakarta, hlm.69

${ }^{26}$ Hartanto, Pengadilan Hak Asasi Manusia dan Mahkamah Pidana Internasional (ICC), Jurnal Pranata, Edisi September 2016, hlm 40

${ }^{27}$ Ibid, hlm 41

${ }^{28}$ Sinta Agustina, 2006, Hukum Pidana Internasional Dalam Teori dan Praktek, Andalas Universty Press, Padang, hlm. 82.

${ }^{29}$ Op.Cit, Eddy O.S Hiariej, hlm. 70-71

${ }^{30}$ Lihat Pasal 5 Statuta Roma Mahkamah Pidana Internasional Tahun 1998 
Pasal 6 menjelaskan unsur-unsur, "genosida" berarti setiap tindakan berikut ini yang dilakukan dengan maksud untuk menghancurkan, secara keseluruhan ataupun sebagian, kelompok bangsa, etnis, ras atau agama seperti:

a) Pembunuhan para anggota kelompok;

b) Menyebabkan kerusakan/luka-luka tubuh ataupun mental yang sangat serius terhadap para anggota kelompok;

c) Dengan sengaja merugikan kondisi-kondisi kehidupan kelompok yang diperhitungkah dapat berakibat pada kerusakan fisik secara keseluruh $\neg$ an ataupun sebagian;

d) Tindakan-tindakan berat yang dimaksudkan untuk mencegah kela $\neg$ hiran kelompok itu;

e) Pemindahan paksa anak-anak dari suatu kelompok ke kelompok lain;

Pasal 7 Statuta menjelaskan tentang unsur-unsur "kejahatan terhadap kemanusiaan" berarti setiap tindakan-tindakan berikut ini apabila dilakukan sebagai bagian dari upaya penyerangan yang sistematis dan menyebar luas yang diarahkan terhadap salah satu kelompok penduduk sipil, dengan penyerangan yang disengaja:

b) Pembunuhan;

c) Pembasmian;

d) Perbudakan;

e) Deportasi atau pemindahan paksa penduduk;

f) Pemenjaraan atau tekanan-tekanan kebebasan fisik yang kejam yang melanggar peraturan dasar hukum internasional;

g) Penyiksaan;

h) Perbudakan seksual, prostitusi paksa, kehamilan paksa, sterili $\neg$ sasi paksa, atau bentuk-bentuk pelanggaran seksual lainnya dengan tingkat keseriusan yang dapat diperbandingkan;

i) Tuntutan terhadap kelompok tertentu yang dapat diidentifikasi atau dilakukan secara bersama-sama dalam bidang politik, ras, bangsa, etnik, budaya, agama, jenis kelamin sebagaimana di-jelaskan pada ayat 3, atau dasar-dasar lain yang secara universal dikenal sebagai hal yang tidak dapat diizinkan sesuai dengan $\mathrm{hu} \neg \mathrm{kum}$ internasional, sehubungan dengan suatu tindakan yang 'disebutkan pada ayat ini atau kejahatan dalam yurisdiksi Pengadilan itu;

a. Penculikan/penghilangan paksa seseorang;

b. Kejahatan apartheid;

c. Tindakan-tindakan tidak berperikemanusian lain dari sifat yang sama yang secara sengaja menyebabkan penderitaan yang besar atau kecelakaan yang serius terhadap tubuh atau mental atau kesehatan fisik;

Untuk tujuan ayat 1Pasal 7 Statuta Roma dijelaskan bahwa :

a) "Penyerangan" yang diarahkan terhadap penduduk sipil" berarti suatu tindakan yang melibatkan perbuatan tindakan yang berlipat ganda yang disebutkan pada ayat 1 terhadap penduduk sipil, sesuai dengan atau merupakan kelanjutan dari kebijakan suatu negara atau organisasi untuk melakukan penyerangan itu;

b) "Pemusnahan" mencakup hukuman atau yang disengaja dari kondisi-kondisi penyiksaan kehidupan, antara lain perampasan akses terhadap makanan dan obat-obatan yang diperhitungkan membawa akibat kerusakan dari bagian suatu populasi; 
c) "Perbudakan" yaitu pelaksanaan salah satu atau semua kekua $\neg$ saan yang melekat pada hak kepemilikan seseorang dan termasuk pelaksanaan kekuasaan itu dalam pelaksanaan perdagang $\neg$ an orang, pada khususnya wanita dan anak-anak;

d) "Deportasi atau pemindahan penduduk secara paksa" yaitu pemindahan paksa orangorang yang terkait dengan pengusiran atau tindakan-tindakan lain dari daerah dimana mereka secara hukum berada, tanpa dasar-dasar yang diizinkan sesuai dengan hukum internasional;

e) "Penyiksaan" yaitu penyiksaan yang disengaja dari rasa sakit yang sangat berat atau menderita, baik secara fisik maupun mental pada seseorang yang berada dalam penjagaan atau di bawah kontrol dari terdakwa; kecuali bahwa penyiksaan itu tidak termasuk rasa sakit atau menderita yang timbul hanya dari, yang menjadi sifat atau secara tidak disengaja dari sanksi-sanksi hukum;

f) "Kehamilan yang dipaksa" yaitu pengurungan yang tidak berdasarkan hukum dari seorang wanita yang dipaksa untuk hamil, dengan maksud mempengaruhi komposisi etnis dari suatu populasi atau melakukan pelanggaran-pelanggaran berat lain dari hukum internasional. Definisi ini bagaimanapun juga tidak boleh diinterpretasikan mempengaruhi hukum nasional yang berhubungan dengan kehamilan;

g) "Penganiayaan" yaitu perampasan yang disengaja dan kejam dari hak-hak dasar yang bertentangan dengan hukum internasional dengan alasan identitas dari kelompok atau pengelompokan;

h) "Kejahatan Apartheid" yaitu tindakan-tindakan yang tidak berperikemanusian dari sifat yang serupa dengan tindakan-tindakan yang disebutkan pada ayat 1, yang dilakukan dalam konteks rezim yang dilembagakan dari penekanan sistematis dan dominasi sistematis oleh salah satu kelompok ras terhadap kelompok ras lain atau beberapa kelompok dan dilakukan dengan maksud untuk menjaga rezim itu:

i) "Penghilangan paksa orang" yaitu pcnangkapan, penahanan, atau penculikan orang-orang oleh atau dengan kewenangan, du $\neg$ kungan, atau pengakuan dari Negara atau organisasi politik yang diikuti dengan penolakan untuk mengakui bahwa perampasan kebebasan atau untuk memberikan informasi tentang martabat atau keberadaan dari orang-orang itu, dengan maksud menghiᄀlangkannya dari perlindungan hukum untuk jangka waktu yang lama.

Untuk tujuan Statuta ini, hal ini dipahami bahwa istilah "jenis kelamin" merujuk pada dua jenis kelamin dalam konteks masyarakat, yaitu laki-laki dan perempuan. Istilah "gender" tidak menunjukan adanya pengertian yang berbeda seperti di atas.

Persoalan pertanggungjawaban negara dalam penyelesaian pelanggaran HAM berat (the most serious crimes of international concern), menarik untuk dikaji, karena baik dalam hukum internasional maupun hukum nasional yang diadopsi dan dikenal adalah pertanggungjawaban pidana individual (individual criminal responsibility), dan belum menyentuh pertanggungjawaban pidana negara (state criminal responsibility). Kejahatan melawan hukum internasional dalam hal ini dilakukan oleh orang, bukan entitas abstrak, sehingga pidana hanya bisa dijatuhkan kepada individu yang melakukan kejahatan tersebut. ${ }^{31}$

\footnotetext{
${ }^{31}$ Krisdiana Katiandagho, 2016, Kewenangan Mahkamah Pidana Internasional Untuk Mengadili Pelaku Kejahatanpelanggaran Ham Berat Dalam Suatu Negara Tanpa Adanya Permintaan Dari Negara Tuan Rumah, Fakultas Hukum, Universitas Atma Jaya Yogyakarta, hlm.7
} 
Menurut Pasal 25 Statuta Roma "Seseorang yang melakukan kejahatan di dalam yurisdiksi Pengadilan itu harus bertanggung jawab secara individu dan mempertanggung jawabkan untuk hukuman". Dapat digarisbawahi bahwa yang menjadi yuridiksi Mahkamah Pidana Internasional ialah pertanggungjawaban secara individu (persons). Terlepas ia seorang pemimpin atau aparatur negara maupun warga sipil.

Dinamika perkembangan doktrin tanggungjawab komando menunjukkan adanya pergeseran penerapan standar mens rea (unsur kesengajaan) dari pertangunggjawaban yang mutlak (strict liability) kepada pertanggungjawaban terbatas (limited liability). Meskipun terdapat variasi dalam praktekinternasional dan nasional, dikenal tiga unsur utama dari doktrin tanggung jawab komando, yaitu: unsur hubungan antara atasan dan bawahan; unsur kesengajaan (mens rea), dan unsur tindakan yang diharuskan. ${ }^{32}$

Myanmar tidak meratifikasi seluruh Statuta Roma, meskipun demikian Mahkamah Pidana Internasional (ICC) dapat mengambil alih kasus ini jika Myanmar dianggap tidak mampu menyelesaikan dan mengadili kasus ini seperti yang termuat dalam Pasal 17 ayat (1) huruf (a) "Kasus itu diselidiki atau dituntut oleh Negara yang mempunyai yurisdiksi terhadapnya, kecuali Negara itu tidak menghendaki atau tidak mampu untuk melakukan investigasi atau penuntutan itu"

Terkait sanksi hukum terhadap Myanmar yang dapat diberikan ICC dapat merujuk Pasal 25 Ayat (2) Statuta Roma "Seseorang yang melakukan kejahatan di dalam yurisdiksi Pengadilan itu harus bertanggung jawab secara individu dan mempertanggung jawabkan untuk hukuman sesuai dengan Statuta ini" dan Pasal 27 "Statuta ini berlaku sama bagi semua orang tanpa ada perbe $\neg$ daan berdasarkan kapasitas resmi. Pada khususnya, kapasitas resmi sebagai Kepala Negara atau Pemerintahan, anggota Pemerintahan atau parlemen, perwakilan terpilih atau pejabat pemerintah dalam kedudukan apapun adalah orang yang tidak akan dibebaskan dari tanggung jawab pidana sesuai dengan Statuta ini, ataupun atas nama dirinya sendiri, tidak merupakan dasar untuk pengurangan hukuman"

Mekanisme lain dapat dilakukan melalui Dewan HAM PBB dengn mekanisme Complaint Procedure yang membuka peluang untuk individu atau organisasi sebagai pelapor dan dilanjutkan dengan Special Procedure yang dapat dilakukan para ahli ndependen dengan mandat dari Dewan HAM PBB. Seluruh prosedur ini disebut dengan Charter Based Mecanism yang menggunakan Piagam PBB sebagai dasar bagi Dewan HAM PBB.

\section{Penutup}

Hukum internasional telah menyediakan regulasi tentang perlindungan terhadap kemanusiaan, baik itu terhadap hak sipil maupun politik. Kejahatan terhadap kemanusiaan sangat bertentangan dengan hukum internasional baik berupa kejahatan yang dilakukan dalam perang, genosida, invansi maupun agresi. Penjahat kemanusiaan seharusnya dapat diadili di International Crminal Court (ICC)/ Mahkamah Pidana Internasional namun karena banyaknya permainan politik internasional banyak yang tidak tersentuh oleh hukum internasional. Kekuatan negara sangat mempengaruhi penegakan hukum internasional.

32 Natsri Anshari, Tanggung Jawab Komando Menurut Hukum Internasional Dan Hukum Nasional Indonesia, Dalam Jurnal Hukum Humaniter, Vol 1 No. 1 Edisi 2005, Jakarta, Pusat Studi Hukum Humaniter dan HAM Universitas Trisakti, hlm. 50 


\section{Daftar Pustaka}

Brownlie(Penerjemah:Beriansyah), Kompilasi Konvensi Tentang Pencegahan Dan Hukuman Terhadap Kejahatan Pemusnahan Suatu Bangsa Dengan Sengaja Tahun 1948, Jakarta: UI Press, 1999.

Eddy O.S Hiariej, Pengantar Hukum Pidana Internasional, Jakarta: Erlangga, 1999.

Hartanto, Pengadilan Hak Asasi Manusia dan Mahkamah Pidana Internasional (ICC), Jurnal Pranata, Edisi September 2016.

Krisdiana Katiandagho,Kewenangan Mahkamah Pidana Internasional Untuk Mengadili Pelaku Kejahatanpelanggaran Ham Berat Dalam Suatu Negara Tanpa Adanya Permintaan Dari Negara Tuan Rumah, Fakultas Hukum, Universitas Atma Jaya Yogyakarta, 2016.

Natsri Anshari, Tanggung Jawab Komando Menurut Hukum Internasional Dan Hukum Nasional Indonesia, Jurnal Hukum Humaniter, Vol 1 No. 1 Edisi 2005, Jakarta, Pusat Studi Hukum Humaniter dan HAM Universitas Trisakti Jakarta.

Sinta Agustina, Hukum Pidana Internasional Dalam Teori dan Praktek, Padang: Andalas Universty Press, 2006.

Sorjono soekanto, Penelitian hukum Normatif, Jakarta: PT Raja Grafindo Persada, 2006.

M.Cherif Bassiouni, 1986, International criminal law

Ridwanul Hoque (16 March 2016). "Asian cHlmlenge". D+C, development and cooperation Selth, Andrew ,Burma's Muslims: Terrorists or Terrorised?. Australia: Strategic and Defence Studies Centre, 2003, Australian National University. p. 7. ISBN 073155437X.

Deklarasi Sedunia Tentang Hak Asasi Manusia Tahun 1948

Konvensi Tentang Pencegahan Dan Hukuman Terhadap Kejahatan Pemusnahan Suatu Bangsa Dengan Sengaja Tahun 1948

Deklarasi Hak Asasi Anak Tahun 1959

Konvensi Internasional Tentang Hak Sipil Dan Politik Tahun 1966

Deklarasi Tentang Perlindungan Dari Penyiksaan tahun 1975

Statuta Roma Mahkamah Pidana Internasional Tahun 1998 https://www.petisionline.net./hentikan\%20pembantaian\%20dan\%20pemusnahan\%20rohingya\% 20-\%20petisionline.net.html, diakses pada 5 Desember 2017,Pukul 10.53 Wib.

https://www.hrw.org/report/2013/04/22/all-you-can-do-pray/crimes-against-humanity-andethnic-cleansing-rohingya-muslims, diakses 27 November 2017, Pukul 11.24. Wib

https:// http://www.genocidewatch.org/aboutgenocide/8stagesofgenocide.html. diakses 27 November 2017, Pukul 11.24. Wib

https://id.wikipedia.org/wiki/rohingya, diakses 30 November 2017. Pukul 10.52 WIB

https://www.republika.co.id, Anak-Anak Rohingya yang Didera Gizi Buruk, Oleh: Crystal Liestia Purnama, diakses 5 Desember 2017.Pukul 10.53 Wib

http://internasional.republika.co.id/berita/internasional/global/17/09/03/ovp7fi-sejarah-singkatrohingya-di-myanmar, diakses 30 November 2017. Pukul 10.57 WIB

https://id.wikipedia.org/wiki/Rohingya\#CITEREFCrisis_Group2014 